\title{
Elegy for a Love Still Breathing
}

\section{J. S. Campion, University of Warwick}

\section{Abstract}

Within this poem, I wanted to explore the nuance within Achilles and Patroclus' dynamic, taking a romantic interpretation of their relationship. After reading the Iliad by Homer, I have been fascinated by the ways in which these characters contrast each other; though both men are powerful fighters, Homer pays particular attention to Patroclus' kindness and often presents him as Achilles' narrative foil. I was interested in exploring why a character such as Patroclus, who is depicted by his gentleness, would choose to remain by the side of somebody as prideful and aggressive as Achilles. This is something which other authors have previously presented in many different ways. For example, Madeline Miller's novel The Song of Achilles (2011) presents Patroclus as a gentle individual who dislikes fighting, though within my own poem I wanted to acknowledge Patroclus' capacity for violence when war necessitates that he kills enemy soldiers. Therefore, I experimented with the idea that Patroclus' resentment at Achilles' actions might manifest itself in the form of violent desires despite his great loyalty to, and love for, Achilles. To explore this conflict and bittersweet love within their relationship, I used the stereotypically romantic form of the sonnet. Furthermore, Patroclus' sense of infatuation begins and ends the poem, as I wanted to highlight his tragic entrapment within his feelings for Achilles.

\section{Elegy for a Love Still Breathing}

The earth would tear itself at every seam to boast your perfect feet had kissed its maw, but in your eyes the heavens' battles teem. I carved a home beside embodied war. Your fingertips and lips and white-toothed gleam all haunt me; now you're only tooth and claw. On sleepless nights I grip my knife and dream it finds the tender flesh beneath your jaw. It won't, I can't, my need for you won't yield. 
Alone, my name is glass or foreign bone, and breaks without Achilles as its shield. The world will swallow me if I'm alone. Your shadow tastes like poisoned wine to me, but love, where else could your Patroclus be?

To cite this paper please use the following details: Campion, J. S. (2022), 'Elegy for a Love Still Breathing', Reinvention: an International Journal of Undergraduate Research, Special Issue | Reeling and Writhing: Intertextuality and Myth, https://reinventionjournal.org/article/view/983. Date accessed [insert date]. If you cite this article or use it in any teaching or other related activities please let us know by e-mailing us at Reinventionjournal@warwick.ac.uk. 